\title{
Proposal of Applying the Exercise Program for the Prevention of Work-related Chronic Low Back Pain
}

\author{
Yeong-Ae Yang ${ }^{1,7}$, Seong-Su Kim ${ }^{2}$, Jin-Gang Hur ${ }^{3}$, Sun-Joung An ${ }^{1}$, Hee-Soo Kim ${ }^{4}$, \\ Su-Min Cha ${ }^{4}$, Jun Heo, ${ }^{5,7}$, Yun-Hee Park ${ }^{6}$, Bo-Ra Park ${ }^{6,7}$ \\ ${ }^{1}$ Department of Occupational Therapy, College of Biomedical Science and Engineering, \\ Inje University, Gimhae, 621-749 \\ ${ }^{2}$ Department of Physical therapy, Gwangju Health College University, Gwangju, 506-701 \\ ${ }^{3}$ Department of Physical Therapy, Hallym University College, Chuncheon, 200-711 \\ ${ }^{4}$ Department of Occupational Therapy, Kangdong Sacred Heart Hospital, Hallym Medical Center, Seoul, 134-701 \\ ${ }^{5}$ Department of Occupational Therapy, Graduate School of Inje University, Gimhae, 621-749 \\ ${ }^{6}$ Department of Rehabilitation Science, Graduate School of Inje University, Gimhae, 621-749 \\ ${ }^{7}$ Institute of Aged Life Redesign, Gimhae, 621-749
}

\begin{abstract}
Objective: The purpose of this research is to provide exercise programs for the prevention of work related chronic back pain. Background: In order to prevent musculoskeletal disease, including proper medical care health promotion programs are needed. Method: This is a research of musculoskeletal disease looking at 618 workers working at a car engine manufacturing factory from April to July of 2008. Through questionnaire specific areas of musculoskeletal diseases experienced by the workers were identified and preventative exercise program for chronic low back pain was recommended. Result: Research showed that of the musculoskeletal disease experienced by the workers, 197 presented with low back pain, 171 presented with shoulder pain, 64 presented with neck pain and 44 presented with knee pain. The symptoms of low back pain included stiffness(143), twinge and burning sensation(24) and absence of sensation(19). Using this result 4 types of exercise programs were recommended for prevention of chronic low back pain. Conclusion: Preventative exercise programs recommended for the workers in this research is easily accessible for the workers. Use of the suggested exercise programs will inevitably decrease work related low back pain. Also 2 other recommendations were made: 1) Internal structural change may be necessary using ergonomics. 2) More exercise programs to be used to increase adaptation and tolerance of joints and muscles that are constantly used for repetitive work. Application: This study can be used to provide for the prevention of work-related Chronic Low Back pain.
\end{abstract}

Keywords: Musculoskeletal Disease, Transverse-abdominis, Work habit, Low back pain

\section{Introduction}

오늘날 고도의 산업화로 발전된 현대 사회는 인간에게
수많은 편리함을 제공하였지만, 산업화에 따라 가중되는 산 업재해의 위험성도 인류건강을 위협하는 한 요인으로 주목 받게 만들고 있다(Henderson, 1983). 현대 산업사회의 기 술발달과 기계화, 자동화에 의해 근로자들의 작업형태는 규

Corresponding Author: Yang Yeong-Ae. Department of Occupational Therapy, College of Biomedical Science and Engineering, Inje University, Gimhae, 621-749.

Mobile: 010-7227-6853, E-mail: otyya62@inje.ac.kr

Copyright@2011 by Ergonomics Society of Korea(pISSN:1229-1684 eISSN:2093-8462). All right reserved. 
칙적이고 기계적인 단순반복 작업으로 세분화되며, 노동환경 에 많은 변화를 가져 왔다. 이러한 노동환경의 다양한 변화 는 작업자에게 육체적, 정신적 부하를 증가시켜 근골격계 질환을 증가시키는 주요 요인으로 자리 잡았다. 이는 국내에 서도 전체 직업성 질환 가운데 근골격계 질환이 차지하는 비율이 해마다 증가하고 있는 현상과 관련 통계자료에서 반 증되고 있는 사실이다(Kim, 2001).

근골격계 질환은 육체적 활동을 해야 하는 모든 생산 현 장에서 신체 활동 능력 저하를 가져오고 생산성 저하를 초 래하는 심각한 문제점을 내포하고 있다(O'Donnell, 1995). 선진국에서도 근골격계 질환이 여러 직종으로 더욱 확산되 고 있고 직업병의 상위를 차지하고 있어 생산손실과 요양비 지출로 인한 재정문제 등이 심화되고 있다(OSHA, 2000). 근골격계 질환의 증가는 생산성 저하, 근로의욕 저하, 품질 저하, 의료비의 부담 증가 등으로 경영손실은 물론, 보상 및 작업개선에 대한 노사 간의 대립에서도 해결의 실마리를 쉽게 찾기는 힘든 상황이다(Lee and Kim, 2005). 2004년 노동부가 발표한 2003년 산업재해 통계에서는 업무상 질 병자수가 9,130명으로 전년도 5,417 명에 비해 3,713명 (68.5\%)이 증가하였으며, 이 중에서 작업관련성 발병은 전 년보다 $77.7 \%$ 증가한 것으로 발표하였다. 2006년에 발표 한 노동부의 재해 통계 보고에 따르면 국내의 근골격계 질 환 보고 건수는 1999년 344건, 2000년 1,009건, 2001년 1,598건, 2002년 1,827건, 2003년 4,532건, 2004년 4,112 건으로 지속적인 증가율을 보였으나, 2005년에는 2,901건 으로 산업재해자수가 $29.5 \%$ 감소한 것으로 보고하였다. 정 부는 그 원인을 2003 년부터 시행한 근골격계 질환에 대한 유해요인 조사 및 예방 조치가 큰 효과를 거둔 것으로 해석 하고 있다(Ministry, 2006). 그러나 정부에서는 정부의 노 력으로 2005년을 기점으로 근골격계 질환자 수가 줄어들고 있다고 발표했지만 이를 신뢰하는 곳은 어디에서도 찾기 어 려운 상황이며, 오히려 이해집단 간에 새로운 논쟁의 단초만 을 제공하고 있는 상황이다(Lee and Kim, 2005). Lee (2007)의 연구 분석 결과에서도 국내 사업장 중 건강증진 사업을 실시하는 곳은 $78 \%$ 정도로 높으나, 실제 각 사업장 별 특성에 맞는 개별화된 건강증진사업을 실시하고 있는 곳은 $1 \%$ 미만으로 파악되었다. 반면, 건강증진을 위한 사업 장정보화에 대한 요구도는 매우 높아 $90 \%$ 이상이 매우 필 요하다고 응답한 것으로 파악되었다. 근골격계 질환은 일단 발병하면 완전히 제 기능을 찾는데 많은 시간이 필요하고 그 기간에 작업손실 등 경제적 손실도 적지 않으므로 무엇 보다 예방하는 것이 중요하다(Kim et al., 2003). 예방을 위 해서는 적절한 의학적 조치를 포함한 건강증진 프로그램이 필요하다. 적절한 의학적 조치란 스트레칭, 운동처방 및 테 이핑 등의 자체적인 조치와 부위고정, 물리치료, 주사요법,
근무 중 치료 및 해당 신체부위 휴식(근로 금지, 제한, 작업 전환) 등을 말한다(Kim, 2004). 이러한 건강증진 프로그램 은 사업장 내에서 작업시간 내에 동시에 실현되는 것이 더 욱 효과적이며, 사업장은 몇 가지 이유로 인해 건강증진 프 로그램을 적용하기에 매우 좋은 장소이다.

첫째, 깨어있는 시간의 대부분을 사업장에서 보내기 때문 에 목표인구에 쉽게 도달할 수 있다(Lee, 2007).

둘째, 사업장은 고용인의 건강에 긍정적인 방법과 부정적 인 방법 모두를 영향 받게 만들 수 있는 곳이다(Agnes J, 2005). 따라서 건강증진 프로그램의 유효성에 따라 긍정적 인 영향을 이끌어내고 부정적인 영향을 최소화 할 수 있는 곳이다.

셋째, 사업장은 근로자의 산업보건 활동을 수행하는 기초 적이면서도 가장 중요한 장으로 근로자 건강진단, 작업환경 측정 결과 등 많은 자료들이 산재되어 있는 곳이기 때문이다 (Ha et al., 1998). 따라서 근골격계 증상 완화 및 예방을 포함한 근골격계 질환자의 감소를 위하여 작업 특성, 증상 특성을 고려한 맞춤식 예방프로그램의 개발이 필요하다. 프 로그램 구성항목은 운동, 작업분석, 작업공정과 작업장 개선 등 여러 부분으로 나눌 수 있으나, 본 연구에서는 작업장 환경 내에서 사용할 수 있는 운동프로그램을 실시한다. 또한 작업습관에 따른 생활습관을 이용한 예방운동 프로그램의 제안으로 근로자의 건강증진 및 향상을 유도할 것이다. 현실 적으로 운동을 통한 건강증진 프로그램의 사업장 내 적용은 노사 간 모두에게 신체적, 심리적 측면에서의 이익과 경제적 효과를 가져다 줄 것으로 기대된다. 이와 관련해 작업동작과 유사한 프로그램을 개발하여 제안하고자 한다. 운동프로그램 은 기존의 방법과 차별화하여 복횡근을 이용한 요부안정화 프로그램을 적용하며, 만성요통 예방을 위하여 제안한다.

\section{Method}

\subsection{Research process}

본 연구는 <그림 1 >과 같은 순서로 구성되어 시행되었다.

\subsection{Study target selection and method}

연구대상자는 00자동차엔진공장에서 사무직을 제외한 생 산직 근로자를 대상으로 하였으며, 근무시간의 대부분을 서 서 작업하는 근로자로 제한하였다.

연구기간은 2008년 4월부터 7월까지이며, 사업장 근골격 계 실태 조사는 618 명을 대상으로 조사하였고, 운동프로그 램은 사업장 내 건강관리실에서 물리치료를 받은 근골격계 
환자 중 요부통증을 호소하는 31명을 대상으로 하였다. 연 구대상자의 일반적인 특성은 다음과 같다(표 1).

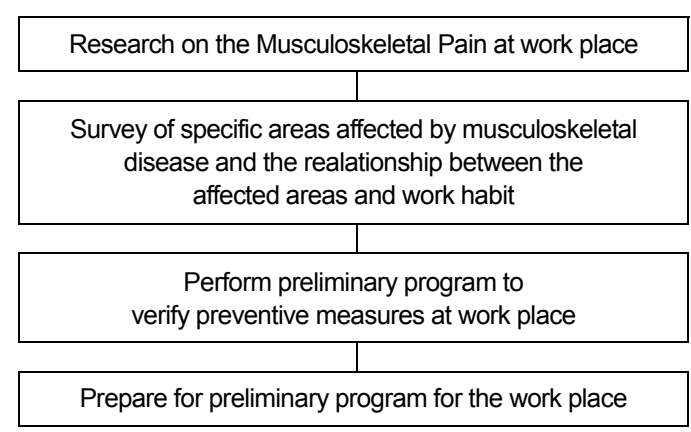

Figure 1. Research process

Table 1. Basic information of the subjects in this study

\begin{tabular}{c|c|c|r|r|c}
\hline & $\mathrm{N}$ & Minimum & Max & \multicolumn{1}{c}{ Mean } & SD \\
\hline Age & 31 & 33 & 51 & 40.16 & 4.65 \\
\hline Height $(\mathrm{cm})$ & 31 & 162 & 188 & 172.48 & 5.50 \\
\hline Weight $(\mathrm{kg})$ & 31 & 61 & 95 & 71.84 & 7.68 \\
\hline
\end{tabular}

한 달 동안 타박상 등을 제외한 반복 작업성 근골격계 질 환자들을 대상으로 작업습관과 관련된 운동치료 프로그램을 제공하였다. 근골격계 질환 실태는 치료 기록지에 기재된 내 용을 중심으로 부위 및 증상, 그리고 원인 등의 조사를 하였 다. 질환부위 증상 원인과 작업형태 연관성은 제조업장 근 로자들의 자기기입식 설문을 이용하여 파악하였다. 한 달 간 의 예비프로그램 실시 후 만족도를 분석하여 근로자들의 사 업장 내 근골격계 질환 예방프로그램을 구성하였다. 만성요 통 예방을 위한 운동 프로그램은 철저히 작업환경과 허리의 굴곡과 신전을 반복하는 작업습관을 반영하였으며, 사업장 내에서 주로 실시되도록 고려하였다. 조사된 자료는 SPSS 12.0 을 이용하여 기술통계분석을 하였다.

\section{Results}

\subsection{Survey on workplace musculoskeletal disorders}

허리와 어깨부위가 질환부위 분포 중 많은 영역을 차지했 으며 뻐근하다는 증상이 제일 많았고, 찌릿함(작열감포함), 무감각 등의 소수 증상이 있었다. 사업장 근골격계 질환의 실태를 조사한 질환부위별 분포와 증상 분포는 다음의 <그 림 $2>$ 와 같다.

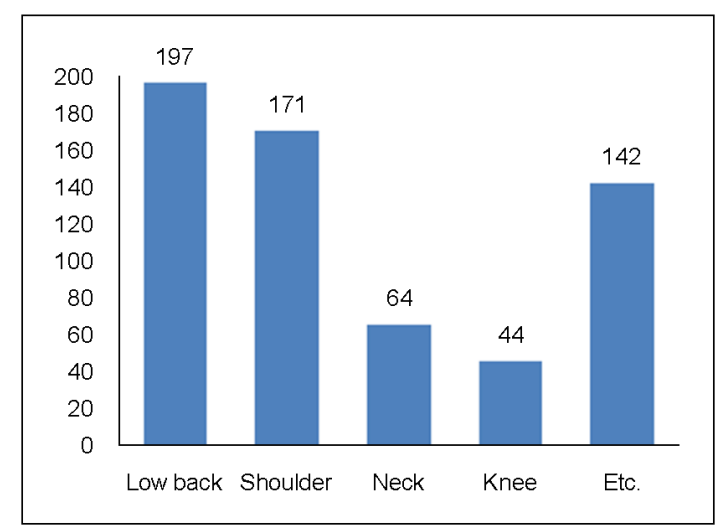

Figure 2. Symptom distribution of affected areas

허리와 어깨부위에 불편을 호소하는 근로자들이 197 명과 171 명으로 많은 분포를 차지했으며, 목 부위가 64명, 무릎 44 명, 기타 손목, 발목, 족부, 주관절 등의 기타 부위가 142 명으로 나타났다.

호소하는 증상은 뻐근함이 허리 143 명, 어깨 119 명, 목 38 명으로 많은 분포를 차지했으며, 찌릿함과 무감각의 순으 로 나타났다. 시리고 우리하다는 등의 기타 증상은 허리 11 명, 어깨 9명, 목 1명으로 나타났다(표 2).

Table 2. Types of symptoms

\begin{tabular}{c|c|c|c|c}
\hline Symptom & Stiffness & $\begin{array}{c}\text { Twinge, } \\
\text { Burning } \\
\text { sensation }\end{array}$ & $\begin{array}{c}\text { Absence of } \\
\text { sensory }\end{array}$ & Etc. \\
\hline Low back & 143 & 24 & 19 & 11 \\
\hline Shoulder & 119 & 35 & 8 & 9 \\
\hline Neck & 38 & 13 & 12 & 1 \\
\hline
\end{tabular}

연구의 주제가 되는 요부통증 원인은 반복적인 작업자세 가 94 명이었고, 외상에 의한 원인이 37 명, 과다한 운동으로 발생된 것이 21 명, 기타 원인 19 명으로 나타났다(표 3).

Table 3. Distribution of the cause of low back pain

\begin{tabular}{c|c|c|c|c}
\hline Cause & $\begin{array}{c}\text { Posture } \\
\text { repetitive }\end{array}$ & Trauma & Exercise & Etc. \\
\hline Low back & 94 & 37 & 21 & 19 \\
\hline
\end{tabular}

\subsubsection{Cause of low back pain according to the form of jobs and work habits}

본 연구의 사업장 내 근골격계 질환 원인 분석 결과 요부 증상 원인은 다음과 같았다<그림 3 >, 〈그림 4>. 


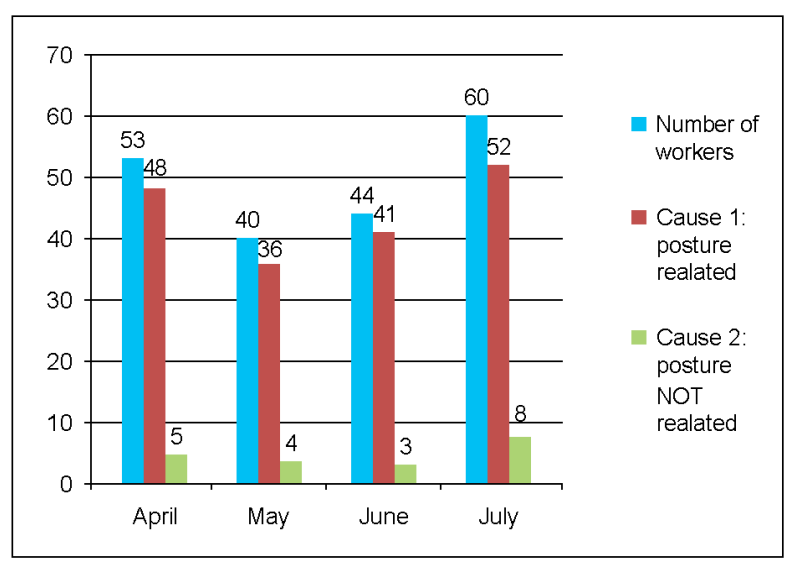

Figure 3. Causes of low back pain

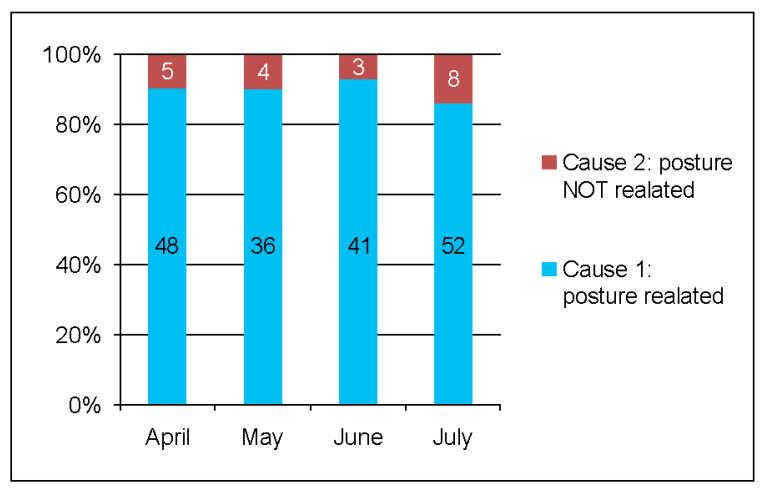

Figure 4. Causes of low back pain(percentile)

<그림 3>, <그림 4>에서 나타난 것처럼 요부에 증상을 호소하는 인원을 대상으로 조사한 결과 작업자세가 원인인 것이 $90.1 \%$ 로 조사됐으며, 작업 외의 원인은 $10 \%$ 미만인 것으로 나타났다.

작업 외의 원인으로는 외상, 과다한 운동, 원인 모름 등이 있었다. 작업자세 원인을 분석한 결과 〈그림 5>, 〈그림 6>, <그림 7>의 작업형태가 많았으며, 〈그림 5>의 작업형태는 본인의 근력 능력보다 과다한 무게를 이동시키기 위한 것들 이 많았고, <그림 6>의 작업형태는 하지의 좌우 균형이 이루 어지지 않은 상태에서 과도한 요부굴곡으로 인해 인체 중심 이 척추에 걸리지 않고 전방쏠림 현상을 만들어내게 되는 동 작이다.

<그림 7>의 작업형태는 무게 중심보다 낮은 작업 장소에 집중되는 힘을 골반의 신장과 하지의 굴곡으로 완화시키며 작업하는 모습이다.

〈그림 5>, 〈그림 6>, 〈그림 7>은 사업장 요통예방운동을 구성하는데 참고하였다.

기초 조사를 통해 사업장근로자의 작업형태와 문제에 따

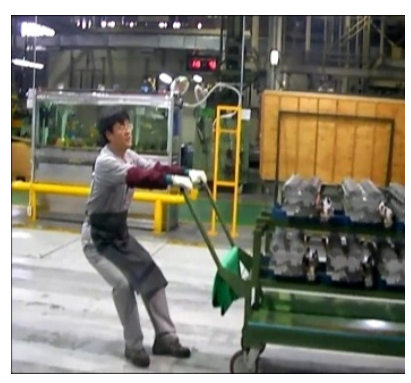

Figure 5. Postures that increase workload on the back which may lead to chronic back pain 1

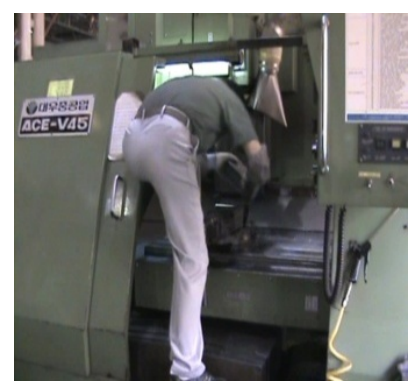

Figure 6. Postures that increase workload on the back which may lead to chronic back pain 2

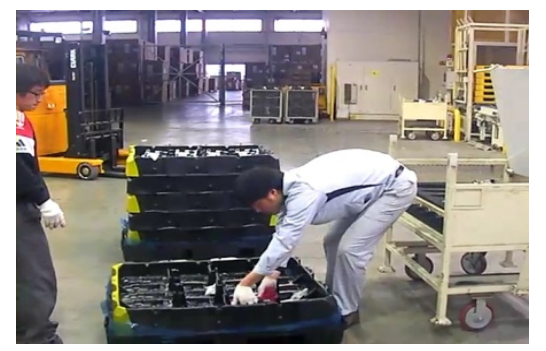

Figure 7. Postures that increase workload on the back which may lead to chronic back pain 3

라 근골격계 질환 중 만성요통 예방을 위해 제안하는 운동 은 다음과 같다. 제안되는 운동은 기존의 연구에서 심부근육 을 트레이닝하여 만성요통 예방과 치료에 효과가 입증된 동 작을 기본으로 구성하였다.

요부에 과부하가 걸리는 동작에서 요추부를 지지하는 척 추근육 중 심부근육에 손상이 오면 외부적으로 상해의 흔 적이 없어도 만성요통의 주요 요인으로 작용한다(No, 2006; Moon, 2008). 또한 복부의 심부근육인 복횡근을 자극하여 〈그림, 8>, 운동시키면 요추를 지지하는 근육 중 큰 역할을 하는 다열근이 동시 수축하여 요통을 예방하거나 줄이는데 효과를 준다<그림 $12>(\mathrm{Kim}, 2008)$.

<그림 8>과 같이 복횡근을 수축하는 방법을 건강관리실에 


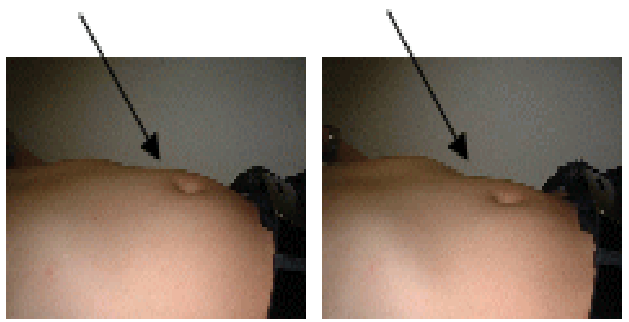

Figure 8. Low back pain prevention exercise program 1

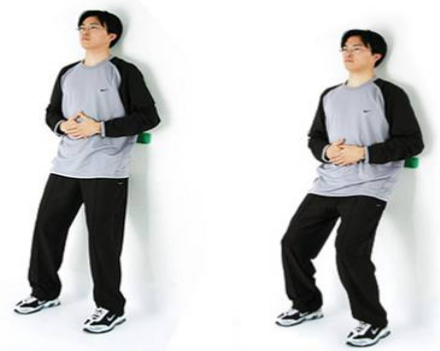

Figure 9. Low back pain prevention exercise program 2

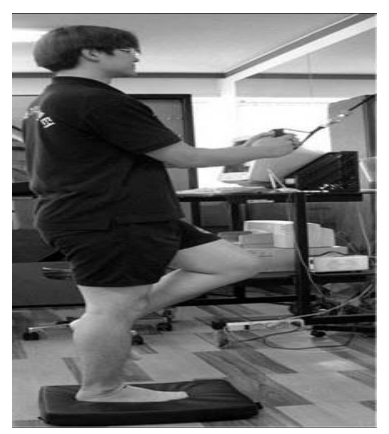

Figure 10. Low back pain prevention exercise program 3
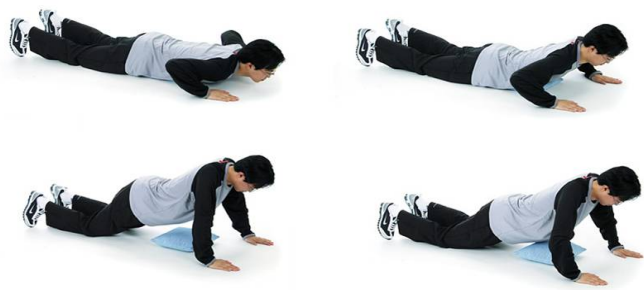

Figure 11. Low back pain prevention exercise program 4

찾아온 근로자를 대상으로 교육시킨 후 그림 $9,10,11$ 의 동작을 숙지시킨다. <그림 9>는 복횡근을 수축하며 벽을 따 라 위아래로 이동하면 복부의 근육과 다열근을 동시에 운동 시킬 수 있다(Kim, 2008).

이 동작은 작업장에서 휴식이나 작업도중 벽에 기대어 쉽
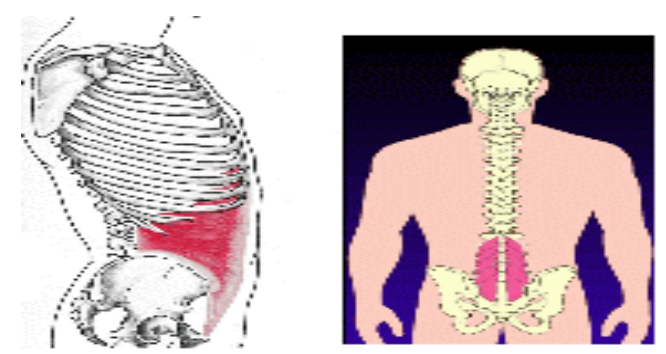

Figure 12. The effects of low back pain prevention exercise (Contraction of transversus abdominis and multifidus)

게 실시할 수 있는 동작이다. <그림 10 >은 한발을 들고 균 형을 잡는 동작으로 30초 유지를 목표로 한다. 30초를 좌, 우 모두 버틸 수 있게 되면 소뇌의 학습 능력이 증대되어 요부의 심부근육이 운동된다. 이것은 운동학습과 소뇌의 연 관성에 관한 결과로 나타나는 것이다(Kim, Jeon, 1994). 숙 련도에 따라 그림과 같이 발밑에 방석이나 쿠션을 받치고 실 시하면 조금 더 높은 강도의 운동이 된다. 이 동작은 작업 중이나 휴식 시 또는 식사대기하는 시간 등에도 부담 없이 실시할 수 있어 효과적이다.

<그림 11 >은 출근 전이나 출근 후 집에서 팔굽혀 펴기를 응용한 동작으로 상체의 부담은 줄이면서 항중력 근육의 역 할로서 복근을 운동시키는 동작(복횡근 수축유지)으로(Paek et al., 2007) 취침 전, 후 가볍게 실시할 수 있는 효과적인 동작이다. 각각의 운동방법에 대한 기본자세, 반복횟수, 휴 식시간, 반복세트, 총 운동시간은 다음과 같다(표 4).

\section{Conclusion}

작업장 내에서 건강관리실이나 물리치료실을 방문하여 증 상을 호소하는 근로자들의 전체적인 신체부위별 분포도를 조사한 연구에서 Lee(2005)은 허리 $36.2 \%$, 어깨 $24.2 \%$, 손목 $11.1 \%$, 목 $5.3 \%$, 무릎 $4.2 \%$ 의 분포를 가지고 있는 것으로 보고하였다. Lee(2001)은 신체부위별 위험요인 노 출률 연구에서 손/ 손목 $49.5 \%$, 어깨 $46.0 \%$, 허리 $32.0 \%$, 목 $28.9 \%$ 등으로 조사하였다.

또한 $\operatorname{Han}$ (2006)은 제조업 근로자와 비제조업 근로자의 작업관련성 근골격계 증상 유병율 조사에서 제조업 근로자 는 $11.0 \%$, 비제조업 근로자는 $9.6 \%$ 로 제조업 근로자의 유 병율이 더 높은 것으로 분석하였다. 또한 사업장 규모별 조 사에서는 500인 이상의 사업장 유병율이 제일 높고, 30인 미만 사업장의 유병율이 제일 낮은 것으로 나타났다.

제조업체 근로자의 직업관련성 근골격계 질환의 유병율 
Table 4. Exercise programs

\begin{tabular}{|c|c|c|c|c|c|}
\hline & Basic stance & Frequency & Rest time & Repeating set & Total exercise time \\
\hline $\begin{array}{l}\text { Up and down } \\
\text { against the wall }\end{array}$ & $\begin{array}{l}\text { Stand with your back against } \\
\text { a wall and feet shoulder-width } \\
\text { apart. Slide down into a } \\
\text { crouch with knees bent. }\end{array}$ & Repeat 10times & $\begin{array}{l}\text { 60seconds rest } \\
\text { between sets }\end{array}$ & 3 set & $\begin{array}{c}10 \mathrm{sec} \times 10 \text { times } \times \\
3 \mathrm{set}=300 \mathrm{sec}+120 \mathrm{sec} \\
\text { of rest, total } 420 \mathrm{sec}\end{array}$ \\
\hline $\begin{array}{l}\text { Maintain balance } \\
\text { while standing } \\
\text { on one leg }\end{array}$ & $\begin{array}{l}\text { Keep transversus abdominis } \\
\text { contracted while standing } \\
\text { on one leg }\end{array}$ & $\begin{array}{l}\text { Repeating it till } 30 \mathrm{sec} \text {. } \\
\text { As much as he can }\end{array}$ & No rest & $\begin{array}{l}\text { Do as much as } \\
\text { he can, in } \\
\text { 5minutes }\end{array}$ & $\begin{array}{l}\text { No more than } \\
5 \text { minutes }\end{array}$ \\
\hline $\begin{array}{l}\text { Advanced } \\
\text { Push up }\end{array}$ & $\begin{array}{l}\text { Push up position by placing } \\
\text { knee on the floor, keep } \\
\text { transversus abdominis } \\
\text { contracted }\end{array}$ & $\begin{array}{l}\text { 10times push up of } \\
\text { 1second-down and } \\
\text { 2seconds-up }\end{array}$ & $\begin{array}{l}60 \mathrm{sec} \text { rest } \\
\text { between sets }\end{array}$ & 3 set & $\begin{array}{l}(3 \mathrm{sec} \times 10 \text { times }) \times \\
3 \mathrm{sets}=90 \mathrm{sec}+120 \mathrm{sec} \\
\text { rest, total } 210 \text { seconds. }\end{array}$ \\
\hline
\end{tabular}

을 분석한 $\operatorname{Kim}(2004)$ 의 연구에서는 어깨 $50.4 \%$, 허리 $40.6 \%$, 다리 및 발이 $35.7 \%$, 목 $34.5 \%$, 손목/손 $30.1 \%$, 팔 24.3\% 순으로 나타났다. Kim et al. (2001)은 자동차 조 립 근로자의 자각증상 보고에서 허리 $73.4 \%$, 목 $66.2 \%$, 어깨 $65.2 \%$, 팔 $42.5 \%$ 의 분포도를 보고하였다.

본 연구는 선행연구의 결과와 같이 유병율이 제일 높은 제 조업체 중 500인 이상의 근로자가 근무하는 사업장을 선정 하였으며, 자동차관련 업체의 근로자를 대상으로 하였다. 선 행연구 결과와 같이 작업관련성 근골격계 질환은 제조업체 근로자의 허리와 어깨부위의 유병율이 가장 높게 나타났으 며, 본 연구의 조사결과도 반복되는 작업자세가 주요 원인 인 것으로 나타났다.

국내 작업관련성 근골격계 질환자로 인정된 807 명을 대상 으로 한 조사연구(Lee, 2001)에서 질환 발생 관련요인은 부적절한 작업자세 요인이 있는 자가 718 명 $(89.0 \%)$, 반복 작업요인 514명(63.7\%), 무리한 힘 요인 428명(53.0\%), 진동요인 53명 $(6.6 \%)$, 신체접촉요인 9명 $(1.1 \%)$ 으로 부적 절한 작업자세 요인이 가장 많았지만, 반복 작업요인, 부적 절한 작업자세 요인, 무리한 힘 요인 등에서 영향이 많았다.

본 연구의 <그림 5 >와 같은 자세는 과다한 무게의 이동 으로 요부에 부담을 주는 자세이다.

Seo and $\operatorname{Im}(1997)$ 의 연구에서 467명의 생산직 근로자 를 대상으로 조사한 연구에서 요통 발생의 원인을 섰다 앉 았다를 반복하는 작업형태 $42.5 \%$, 서서 일하는 작업형태 $40.3 \%$ 에서 무리한 중량물 취급하는 것이 원인으로 조사된 것이 $41.4 \%$ 였다. 이런 동작들은 광배근과 하지근육의 도 움을 받아 전신에 힘을 모으는 형태이다. 광배근이나 하지근 육의 근력이 떨어지면 심부의 척추분절에 불안정성을 가져 오게 된다. 불안정성이 지속되면 척추분절의 흔들림으로 요 통이 발생하게 된다. 이에 관련해 척추분절에 힘을 주는 주 동근육보다 주동근육을 고정해주는 복부근의 강화가 필요하 다. 이것은 3 주간의 복횡근 강화운동으로 척추분절의 안정
성이 향상됨을 보여준 김선엽과 Paek(2003)의 연구 결과 에서도 알 수 있다.

<그림 6>의 자세는 전방으로 집중되는 중력과 체중의 부 하를 요부에서 받아들이게 되며, 반복적인 작업은 요부에 기능적인 문제를 만들어 통증을 야기할 수 있다.

Park(2002)의 연구에서도 요통환자와 일반인을 대상으 로 우세측과 비우세측을 비교한 결과 요통이 있는 실험군에 서 좌우 근육의 불균형이 통계적으로 유의함을 알 수 있다. 예방을 위해서는 전방에 집중되는 과부하를 복근의 힘으로 감소시켜 요부의 압력을 줄여주는 방법이 있다(Oh, 1998; Park, 2003; Ko and Koo, 2004).

<그림 7>과 같은 지속적인 작업의 반복은 신장되는 요부 와 둔부의 근육에 장력의 한계를 느끼게 하고, 이것은 바로 요부의 문제로 연결된다. 요부근육의 장력을 높이고 하지근 육의 근력을 강화하는 것이 요부 질환의 예방방법이며, 이를 위해 하지근육과 둔부근육의 길항근이 되는 복부근육을 강 화시키는 것 (Kim, 2003; Kwun, 2005)이 일차적인 예방방 법이라 할 수 있다.

본 연구의 사업장내 근골격계 질환 원인 분석 결과 요부 증상 원인은 주로 서서하는 작업과정에서 발생되는 반복되 는 자세의 압력을 견디지 못해 발병되는 근골격계 질환으로 척추의 안정화를 이루는 안정화근육의 약화가 주원인인 것 으로 보인다. 또한 <그림 7 >과 같은 부적절한 작업자세의 누적으로 인한 좌우근육 상태의 불균형도 주요한 원인인 것 으로 보인다. <그림 $5,6,7$ >에서 나타난 것과 같이 요부에 과부하가 걸리는 동작이 반복, 지속되면 심부근육에도 영향 을 미쳐 외부적으로 이상이 없어 보여도 본인은 만성적인 통 증을 호소하게 되며, 이러한 증상은 근골격계 질환 중 요통 의 대표적인 현상이다.

예비프로그램 실시 결과 요부에서 안정화를 이루는 복부 근육의 강화와 척추의 정열을 이끌어내는 동작이 주로 효과 를 보았다<그림 $9,10,11$ > 이 동작들은 요부의 심부근육 
을 자극하여 운동시키는 방법을 적용하였다<그림 8>. 요부 의 심부근육운동은 안정화 운동에 의해 요부신전근력이 증 가된다는 논문(Kim, 2008; Kim, 2008)에 기초를 두고 예 비프로그램 운동을 실시하였다. 예비프로그램의 구성은 스 트레칭과 근력강화운동의 구별을 두지 않고 각 부위별 효과 를 극대화 시킬 수 있는 방법들로 구성하였으며, 근력강화 운동은 저항운동을 적용하였다. 저항운동은 미국스포츠의학 회(ACSM, 1998)에서도 근력의 유지, 요통예방 그리고 일 상생활을 원활하게 하기 위해서 권장하고 있다. 실제로 건강 한 일반인뿐만 아니라 질환자를 대상으로 저항성운동의 유 용성이 확인되고 있다(Keleman et al., 1990; LaFontaine, 1997).

또한 Hur (2005)의 연구에서도 다열근과 복횡근을 저항 운동 시켰을 때 요추부 경사각도가 비운동 그룹에 비해 감 소하였다고 보고하였다. 이것은 요추부위 심부근육의 강화가 요추부 경사각도를 감소시켜 디스크에 가해지는 압력의 안 정화를 만들어 요부 질환의 예방에 도움을 줄 수 있음을 알 게 하는 결과이다. 본 연구에서는 자동차관련 제조업체에서 근무하는 근로자들을 대상으로 주요 근골격계 증상 호소부 위를 조사하였으며, 증상들의 원인인 작업동작과 관련한 예 방운동을 제안하였다. 기존의 운동프로그램과 차별을 두기 위하여 <그림 8>의 동작을 사전 교육시켜, 작업장 어디서나 기대서 할 수 있는 <그림 9 >의 동작을 실시하도록 하였다. <그림 10>과 <그림 11>도 <그림 8>의 복횡근 수축운동이 사전 교육된 이후에 실시하여 심부근육의 안정화를 시키도 록 하였다. 제안된 운동방법들은 기존의 프로그램들과 유사 해 보이는 동작들이나 실제 운동의 효과가 만성요통의 주요 원인인 심부근육이 트레이닝 된다(Hodges \& Richardson, 1996; Kim, 2008)는 것이 본 프로 그램의 특징이다.

제안된 동작들은 현실적으로 최대한 유용하게 실시할 수 있도록 프로그램된 것이다. 아무리 좋은 동작이나 효과적인 프로그램이라 하더라도 실천이 동반되지 않으면 의미가 없 어지는 것이 사실이다. 이에 따라 본 연구에서 제안하는 예 방운동프로그램 동작들은 최대한 쉽게 실시하며 고효율의 효과를 얻어내는 방법들로 구성하였다. 또한 운동을 위해 따 로 시간을 내거나 장소를 이동하는 요소를 제거하여 작업장 내에서 자유롭게 실시할 수 있는 프로그램을 제안하였다.

\section{Discussion}

본 연구는 작업관련성 근골격계 질환 유병율이 높은 제조 업체 중에서 자동차관련 사업장근로자들의 허리부위 증상 호소를 완화시키기 위한 예방프로그램의 개발을 목적으로
하였다. 사업장 내의 건강관리실을 방문하여 증상을 호소하 는 근로자들의 전체적인 신체부위별 분포는 허리가 $32 \%$, 어깨 $28 \%$, 목 $10 \%$ 등으로 허리부위 통증비율이 가장 높았 다. 근골격계 질환 증상 호소부위가 높은 허리부위의 발병원 인은 주로 작업관련(허리를 구부렸다 펴는 등의 반복적인 자세)이었고, 반복되는 만성통증이었다.

본 연구의 결과는 여러 형태의 산업 중에서 자동차 산업과 같은 조립작업의 근골격계 질환 유병율이 상대적으로 높았 다. 조사대상이 되었던 사업장의 근골격계 질환의 발생을 예 방하기 위한 대책은 크게 두 가지 방향으로 접근되어야 할 것으로 생각된다.

첫 번째, 작업장 내의 구조와 작업방법 등에 따른 질환 유 발 자세를 개선하기 위한 인간공학적 접근이 필요할 것이다.

두 번째, 지속되는 작업 속에서 관절 및 근육의 적응도와 내성을 기를 수 있는 예방운동이 필요하다.

본 논문에서는 이와 관련해 별도의 장소와 기구 없이 작업 장 내에서 손쉽게 시행할 수 있으며, 효과가 높은 운동방법 을 제안하였다. 또한 복횡근을 이용한 요부 질환 예방운동 프로그램을 실시하여, 기존 운동방법과 차별화를 두었다. 현 실적으로 기타 사업장에서 제안되고 있는 요통예방운동은 특별한 기구를 이용하거나 장소가 필요한 방법들로 실현 가 능성이 적은 것이 사실 이다. 따라서 위에서 제안한 운동방 법들은 조금 더 현장에서 효과적이고 실제적으로 사용되어 요통예방의 현실화에 기여하리라 생각한다.

\section{References}

Agnes Juhasz., Worksite health promotion-A hungarian experiment introduction periodica polytechnica, SER SOC MAN SCL, 13(1), 31-44, 2005.

American College of Sports Medicine, Exercise and physical activity for older adults, Med Sci Sport Exer, 30, 992-1008, 1998.

Ha, E. H., Hong, Y. C., Kim, C. H., Jeon, G. J., Park, H. S., Yang, M. R., Cho, H. S. and Lee, B. E., A Survey for Computerized Health Information System at Occupational Health Care Centers, Healthcare Informatics Research, 4(2), 1998.

Han, B. S., Prevalence of work related musculoskeletal symptoms and relevant factor analysis, PhD thesis, Ewha Women's University, 2006.

Henderson, J., What should be done about occupational accidents and diseases, Int J Epidemiol, 12(1), 77, 1983.

Hodges, P. \& Richardson, C, Inefficient muscular stabiliation of the lumbar spine associated with low back pain, A motor control evaluation of transversus abdominis, Spine, 21(22), 2640-2650, 1996.

Hur, J. G., Effect on Active Exercise Programs in Employees with Chronic Low Back Pain, PhD thesis, Hanyang University, 2005. 
Keleman, M. H., Effron, M. B., Valenti, S. A. \& Stewart, K. J., Exercise training combined with antihypertensive drug therapy: Effects on lipids, blood pressure, and left ventricular mass. J Am Med Assoc, 263, 2766-2771, 1990.

Kim, C. H., A Study of Musculoskeletal Disorders at Automobile Industries in Korea, Korean journal of industrial and systems engineering, 24(67), 1-10, 2001.

Kim, C. S., Kim, G. J., Choi. J. W. and Yun, S. J., The Prevalence Subjective Symptom of Cumulative Trauma Disorders and Related Risk Factors among Workers in Automobile Assembly Plant, Journal of Korea society of occupational and environmental hygiene, 11(1), 85-91, 2001.

Kwun, H. R., The Effect of Self-lumbar exercise program on fitness, pain, and reducing the activity disorder of patients with chronic low back pain, Ewha Womans University, Master's Thesis, 2005.

Kim, H. W., Effects of Intentional Abdominal Muscle Contraction on Lumbar Muscle Activities andLumbar Extension During Lifting Above the Shoulders, Master's thesis, Yonsei University, 2003.

Kim, H. W., Stretching programs are effective in preventing musculoskeletal disorders? How to design and implement this program shall be in effect?

Kim, J. H., Comparing the effects of two different lumbar stabilization exercises on the cross sectional area of he lumbar multifidus muscle in patients with low back pain, Sahmyook University Master's Thesis, 2008.

Kim, M. H. and Jeon, B. S., Motor Learning Induces c-fos Expression in Mouse Cerbellum, J Korean Neurol Assoc, 12(3), 1994.

Kim, S. M., Factors Related to Musculoskeletal Disorders among Some Manufacturing Workers, Inje University school of Public Health, Master's Thesis, 2004.

Kim, S. S., Effects of Lumbar Rehabilitation Exercise on Lumbar Herniated Nucleus Pulposus (HNP)-suffering Patient"s Lumbar Extension Muscle Strength, and Deep Muscle and Scar Tissue in Their Operated Areas, Korea University doctoral dissertation, 2008.

Kim, S. Y. and Paek, I. H., Effects of Transversus Abdominal Muscle Stabilization Exercise to Spinal Segment Motion on Trunk FlexionExtension, Korea Journal of Physical Therapy, 10(1), 2003.

Kim, S. Y., Yun, S. Y. and Kim, H. J., An Analysis of Studies on Workers Musculoskeletal Disorder, The Korean Journal of Occupational Health Nursing, 12(1), 39-49, 2003.

Ko, S. K. and Koo, M. S., Kinesiatrics for the back pain patients, Basic science studies, 21(1), 117-126, 2004.

Lee, K. S. and Kim, J. H., Ergonomic intervention for the reduction of musculoskeletal disorders. Journal of Science and Technology Research, 16, 761-770, 2005.

Lee, S. H., Added information and business needs analysis · policy recommendations for health promotion workers, Master's thesis, Yonsei University, 2007.

Lee, S. J., Musculoskeletal disorders of complex regional workers, survey research, the Asia-Pacific Studies, 4, 2005.

Lee, Y. G., Characteristics of the musculoskeletal diseases and management measures of Automotive assembly operations, occupational health seminars for the Industrial Health Association, No. 9, 2001.

Lee, Y. S., A study on the factors related to the occurrence of work related musculoskeletal disorders, Master's thesis, Yonsei University, 2001.

Ministry of Labor, 2003. Industrial Accident Analysis, 2004. Ministry of Labor, 2005. Industrial Accident status, 2006.

Moon, S. Y., Effects of Core Stabilization Exercise and Resistance Training on Pain Relief and the Change of Center of Gravity in Chronic Low Back Pain Patients, Master's thesis, Keimyung University, Graduate School of Sports Industry, 2008.

No, K. S., Comparison of Muscle Onset Times During Perturbation Between Subjects With and Without Work-Related Chronic Low Back Pain, Master's thesis, Yonsei University, 2006.

O'Donnell, M, P., Workplace health promotion: Report on experiences in the United States, European health promotion series-WHO, 1(6), 1995.

Oh, Y. P., Abdominal strengthening exercises in patients with low back pain affects the erector spinae muscules, Master Thesis, Kookmin University, 1998.

OSHA(Occupational Safety and Health Adminstration). Nonfatal occupational illnesses by category of illness, private industry, U.S Department of Labor, Bureau of Labor Statistics, 2000.

Park, H. S., The effect of electrical therapy before and after the abdominal muscle strengthening exercises using elastic bands in patients with chronic low back pain on muscle strength and joint range, Master's thesis, Dankook University, 2003.

Park, J. H., A study on the muscle balance of the students with low back pain symptom, Master Thesis, Kookmin University, 2002.

Paek, I. H., Kim, S. S., Kim, S. H., Kim, H. C., Seong, K. S., Yu, B. G. and Lee, S. N., Functional exercise therapy for patients with musculoskeletal injuries (MTT), English publisher, 2007.

Seo, S. R. and Im, W. H., A Study on the Cause and the Human Engineering Intervention to the Low back Disorder Developed in the Workplace, Management Sciences, 8(1), 1997.

Spirduso, W. W., Francis, K. L. and MacRae, P. G., Physical dimensions of aging. Champaign: Human Kinetic, 2005

The consecutive number of volumes of Occupational Health, Korean industrial health association, 195, 2004.

\section{Author listings}

\section{Yeong-Ae Yang: otyya62@inje.ac.kr}

Highest degree: Hanyang University, Department of Occupational \& Environment Medicine Dr.

Position title: Inje University, Professor, Department of Occupational Therapy, Institute of Aged Life Redesign

Areas of interest: Occupational therapy, Ergonomics 
Seong-Su Kim: suri1300@ghc.ac.kr

Highest degree: Korea University Department of Physical Education, Ph.D.

Position title: Professor of Physical Therapy, Gwangju Health College University

Areas of interest: Physical therapy

Jin-Gang Hur: jghur7@empal.com

Highest degree: Hanyang University, Department of Occupational \& Environment Medicine Dr.

Position title: Professor of Physical Therapy, Hallym University College Areas of interest: Prevention and Treatment of musculoskeletal disease, movement and posture analysis

Sun-Joung An: sunjoungan@inje.ac.kr

Highest degree: Occupational Therapy, Ph.D.

Position title: Inje University, Professor, Department of Occupational Therapy

Areas of interest: Occupational therapy, Sensory integration

Hee-Soo Kim: otkimhs@empal.com

Highest degree: Hallym University, Department of Occupational Therapy Masters

Position title: Kangdong Sacred Heart Hospital, Hallym Medical Center, department of Rehabilitation medicine, occupational therapy team leader Areas of interest: Motion analysis of the elderly, posture analysis of nervous system diseases

Su-Min Cha: csm1206@hanmail.net

Highest degree: Hallym University, Department of Occupational Therapy Masters

Position title: Kangdong Sacred Heart Hospital, Hallym Medical Center, department of Rehabilitation medicine, occupationa therapy unit unitterest: Occupational therapy, Ergonomics

Areas of interest: Occupational therapy, Ergonomics
Jun Heo: hj1907013@naver.com

Highest degree: Department of Occupational Therapy, Inje University, BA Position title: Inje University, studying Master of Occupational Therapy Department

Areas of interest: Occupational therapy, Ergonomics

Yun-Hee Park: sk8355@hanmail.net

Highest degree: Master's degree in occupational therapy from Inje university

Position title: Occupational therapy, Inje University, Ph.D. studying in rehabilitation science

Areas of interest: Occupational therapy, Ergonomics

Bo-Ra Park: ktx-br@hanmail.net

Highest degree: Hallym University, Department of Occupational Therapy Masters

Position title: Occupational therapy, Inje University, Ph.D. studying in rehabilitation science

Areas of interest: Occupational therapy, Ergonomics

Date Received : 2008-10-21

Date Revised : 2011-06-03

Date Accepted : 2011-06-08 